УДК 334.722:37.01

JEL classification: $M 14$

\author{
доктор економ.наук, професор \\ ORCID ID: 0000-0003-0317-8675 \\ Федірко Г.А. \\ ORCID ID: 0000-0002-3691-7748
}

Дергачова В.B.

Національний технічний університет Украӥни «Київський політехнічний інститут імені Ігоря Сікорського»

\title{
ОСОБЛИВОСТІ ФОРМУВАННЯ КОРПОРАТИВНОЇ КУЛЬТУРИ НА ПІДПРИЕМСТВАХ УКРАЇНИ
}

\section{FEATURES OF FORMING CORPORATE CULTURE ON ENTERPRISES OF UKRAINE}

В статті розглянуто поняття корпоративної культури, як ефективного інструменту управління, який стає пріоритетним фактором ділового успіху, оскільки вона задає орієнтири поведінки: всередині організації, у взаємодії між працівниками на робочому місиі, тому щьо в останній час бізнес все більше залежить від згуртованості та командної роботи колективу, а ие вимагає створення цінностей які об'єднують, правил, які допомагають ефективно працювати усім членам; з часом зникають мотиваційні особливості та персональні потреби персоналу підприємства, які піднімаються на новий рівень; економічні засоби мотивації, не завжди дають ефект, в разі коли є потреба самореалізації працівників колективу. Розглянуто значення та функиї корпоративної культури: надання співробітникам організачійної ідентичності, визначення внутрішнього уявлення про підприємство та його головні иінності; допомога новим співробітникам швидко адаптуватись і прилучитися до ефективної роботи, правильно сприймати явища, щзо відбуваються на підприємстві, завдяки знанням про головні принципи корпоративної культури; стимулювання прояву індивідуальної $i$ колективної відповідальності при виконання окреслених завдань. Охарактеризовано та згруповано зовнішні та внутрішні фактори впливу на формування корпоративної культури підприємства. Розглянуто особливості формування корпоративної культури на украӥнських підприємствах, оскільки багатоаспектність видів економічної діяльності суб'єктів господарювання обумовлює формулювання різноманітних вимог щуодо корпоративної культури в галузевому контексті. Виявлено фактори, щуо визначають специфіку формування корпоративної культури підприємства, залежно від його галузевої приналежності, досліджено, щзо на формування корпоративної культури підприємств суттєвий вплив мають особливості проживання людей у сільській чи міській місцевості, національного буття, національного характеру, суспільної свідомості та психології.

Ключові слова: корпоративна культура, підприємство, організаційна культура, функції корпоративної культури, фактори, особливості формування.

The article considers the notion of corporate culture as an effective management tool, which becomes a priority factor for business success, since it sets the benchmarks for behavior: within the organization, in the interaction between employees in the workplace, because The connection between business performance and the effectiveness of the team work outlines the 
urgency of this topic. At the same time there is a great demand for the creation the values that combine the rules which help all members of any collective work efficiently; as the motivation and employees' personal needs fade over time. The economic means of motivation do not always work well, especially when there is a need of self-realization of every member of the collective. The significance and functions of corporate culture are considered: providing employees with organizational identity, defining the internal image of the; help new employees quickly adapt and join effective work, correctly perceive the phenomena occurring at the enterprise, thanks to knowledge of the main principles of corporate culture; stimulating the manifestation of individual and collective responsibility in the performance of certain tasks The external and internal factors influencing the formation of corporate culture of the enterprise are characterized and grouped. The peculiarities of the formation of corporate culture at Ukrainian enterprises are considered, since multidimensional types of economic activity of business entities causes the formulation of various requirements regarding corporate culture in the sectoral context. The factors determining the specificity of the formation of corporate culture of the enterprise, depending on its branch affiliation, have been investigated, that on the formation of corporate culture of enterprises has a significant impact on the characteristics of people living in rural or urban areas, national existence and national character, social consciousness and psychology.

Keywords: corporate culture, enterprise, organizational culture, functions of corporate culture, factors, peculiarities of formation.

Вступ. Вирішальним фактором успішної роботи вітчизняних підприємств в умовах ринку є формування корпоративної культури.

Актуальність зазначеної теми зумовлена необхідністю створення відповідної концепції та методів формування корпоративної культури як основи стабільного розвитку підприємства в майбутньому.

Важливість корпоративної культури зросла, коли стало очевидним, що складова успіху - це не тільки якісна система надання послуг, але й працівники, що трудяться на підприємстві. Соціально-психологічна атмосфера в колективі, ступінь зацікавленості працівників у сукупній діяльності підприємства зумовлюють підвищення ефективності його діяльності.

Проблемам формування, оцінювання та розвитку корпоративної культури значна увага приділена у працях вітчизняних та зарубіжних науковців, Р.Л. Ансофф, Е.Г. Шейн, М.Р. Богатирьов, А.В. Іванченко, Г.В. Назарова,В.Антонова, I. Бєлікова, В.Вербицького, В. Гретченко, О. Дубовицьку, Д. Ісаєва, Р. Коджоян, М. Самосудова, Г. Хаєта та ін. Але особливостіформування корпоративної культури на підприємствах висвітлені недостатньо, що стало поштовхом для детальнішого дослідження даного питання.

Постановка завдання. Визначити та проаналізувати особливості формування корпоративної культури підприємств України в сучасних умовах з урахуванням галузевої приналежності.

Методологія. В процесі дослідження використовувались філософські методи пізнання та методи економічного і статистичного аналізу. Для 
отримання аналітичної інформації були використані дані статистичної звітності.

Результати дослідження. Ринкове середовище диктує свої правила для українських підприємств різних галузей, в результаті чого вони розуміють те, що не тільки матеріальний капітал $\epsilon$ основою стабільної діяльності та конкурентоспроможності, а й інтелектуальний, моральний та етичний потенціал стає запорукою ефективності та стабільності.

Тому на українських підприємствах поступово починають з'являтись об'єктивні передумови формування корпоративної культури, які полягають зокрема в тому, що пріоритет в економічних процесах повинен надаватись працівникам.

Розвиток людського потенціалу $\epsilon$ головною передумовою та необхідністю формування корпоративної культури на українських підприємствах галузі.

Корпоративну культуру можна розглядати як своєрідну ідеологію управління, націлену на підвищення ділової активності підприємства. Ідеологія управління проявляється в місії та цілях організації і впливає на:

- взаємовідносини працівників із організацією;

- основні принципи діяльності працівників та організації загалом;

- відносини організації до ділових партнерів, конкурентів, споживачів;

- позиціонування щодо суспільства;

- загальні світоглядні позиції [3].

Корпоративна культура тісно взаємопов'язана із діловою етикою, філософією бізнесу, організаційною поведінкою.

Корпоративну культуру можна розглядати і як важливий складник нематеріальних активів, що формує інтелектуальний капітал організації, оскільки вона додає вартість до репутації організації (поняття додаткової вартості)[4].

У сучасному світі корпоративну культуру слід розглядати як інструмент ефективного управління. Сьогодні корпоративна культура стає пріоритетним фактором ділового успіху, оскільки вона задає орієнтири поведінки: всередині організації, у взаємодії між працівниками на робочому місці (культура праці), поза організацією, у взаємодії між різними інституціональними суб'єктами та партнерами по бізнесу.

Основним чинником формування корпоративної культури на українських підприємствах $\epsilon$ те, що вони повинні вдосконалювати свій розвиток згідно тих вимог, які формуються у відповідності до глобального розвитку економіки, щоб у майбутньому не опинитись за межами світових процесів [2].

Корпоративна культура $\epsilon$ невід'ємною складовою колективу в сучасному підприємстві. 3 точки зору системного підходу і колектив, i 
підприємство в цілому є складними відкритими системами, формування яких відбувається під впливом сукупності факторів зовнішнього та внутрішнього середовища. Логічно буде припустити, що ці фактори впливають також і на формування, і на розвиток корпоративної культури підприємств.

Суттєвим фактором в процесі формування корпоративної культури $\epsilon$ врахування галузевих особливостей підприємства. Наведена багатоаспектність видів економічної діяльності суб'єктів господарювання обумовлює формулювання різноманітних вимог щодо корпоративної культури в галузевому контексті.

Загалом обрання галузевої специфіки в сучасному економічному просторі визначається стратегією розвитку підприємства 3 урахуванням впливу зовнішніх чинників економічного, соціального, політичного характеру тощо.

Галузева специфіка формування корпоративної культури не повинна знаходитися в прямій залежності від виду економічної діяльності, яким займається компанія. Для вірного розуміння та обгрунтування цієї позиції важливо дослідити та виокремити фактори, що визначають галузеву специфіку підприємства.

Доцільно використовувати п'ять специфічних ознак, які характеризують галузеву специфіку їх діяльності та визначають специфіку формування корпоративної культури підприємства: 1) сезонність діяльності; 2) публічність; 3) персонал; 4) складність виробничого процесу; 5) конфіденційність облікової інформації [4].

Для вивчення впливу факторів зовнішнього і внутрішнього середовища на корпоративну культуру необхідно[3]:

- виділити найбільш суттєві чинники, які впливають на корпоративну культуру. Їх перелік буде визначатися сферою діяльності підприємства, ситуацією на ринку, ії конкурентним становищем, потенціалом та ін;

- визначити ступінь впливу кожного фактору на корпоративну культуру експертним шляхом через опитування керівників, працівників підприємств галузі;

- проаналізувати отримані результати, визначивши чинники, мають найбільший вплив на корпоративну культуру, напрямки їхнього впливу i можливості впливу на них з метою вдосконалення корпоративної культури.

Групування внутрішніх і зовнішніх факторів впливу на формування корпоративної культури представлено на рис.1.

Корпоративна культура - це система матеріальних і духовних цінностей, притаманних даній корпорації, що відображає іiі індивідуальність, поведінка із сприйняття компанії іншими в навколишньому середовищі.

Розглядаючи структуру корпоративної культури на підприємстві, виділяють три її рівні: 
- зовнішній - властива підприємству символіка, традиції та принципи поведінки на ринку;

- базовий - домінуючі цінності та традиції підприємства певної галузі й норми поведінки, виражені в місії підприємства, відображені в статуті підприємства, правилах внутрішнього розпорядку, регламентах тощо;

- внутрішній - неписані правила взаємин співробітників підприємства як між собою, так і поза його межами [1-4].

Зовнішні і внутрішні фактори впливу на формування корпоративної культури підприємства

\begin{tabular}{|l|l|}
\hline \multicolumn{1}{|c|}{ Зовнішні фактори } & \multicolumn{1}{c|}{ Внутрішні фактори } \\
\hline Низький генофон & Рівень кваліфікації та освіти \\
Інноваційні процеси & працівників \\
Конкуренти & Традиції, міфи, легенди \\
Інтелектуалізація праці & Комунікацї, контакти \\
Споживачі & Кадрова політика,система \\
Економічні процеси в країні & менеджменту \\
Глобалізація та інтернаціоналізація & Мотивація \\
Національна культура та менталітет & Особа замовника та стиль керівництва \\
Політична ситуація & Умови праці та технології \\
Система законодавства & Морально-психологічний клімат та \\
& готовність до змін \\
& Стадія життєвого циклу \\
& Норми, стандарти та етика \\
\hline
\end{tabular}

Рисунок 1 - Зовнішні і внутрішні фактори впливу на формування корпоративної культури підприємства [1-4]

Корпоративна культура має будуватися, у першу чергу, на взаємній довірі вищого менеджменту підприємства та його персоналу. Без такої довіри підприємство перетворюється в бюрократичну структуру лише зовнішніх i базових атрибутів корпоративної культури. Довіра - це внутрішній стрижень, основа, що формує підприємство, перетворює його на те місце, куди хочеться приходити й де хочеться працювати.

Сутність корпоративної культури підприємства характеризується визначеним набором параметрів: набута між членами колективу система стосунків; соціально-психологічний клімат; першочергові цінності; технологія управління; реакція на зміни й т. д.

Формування корпоративної культури на підприємстві здійснюється через функції (рис. 2) [4]. 


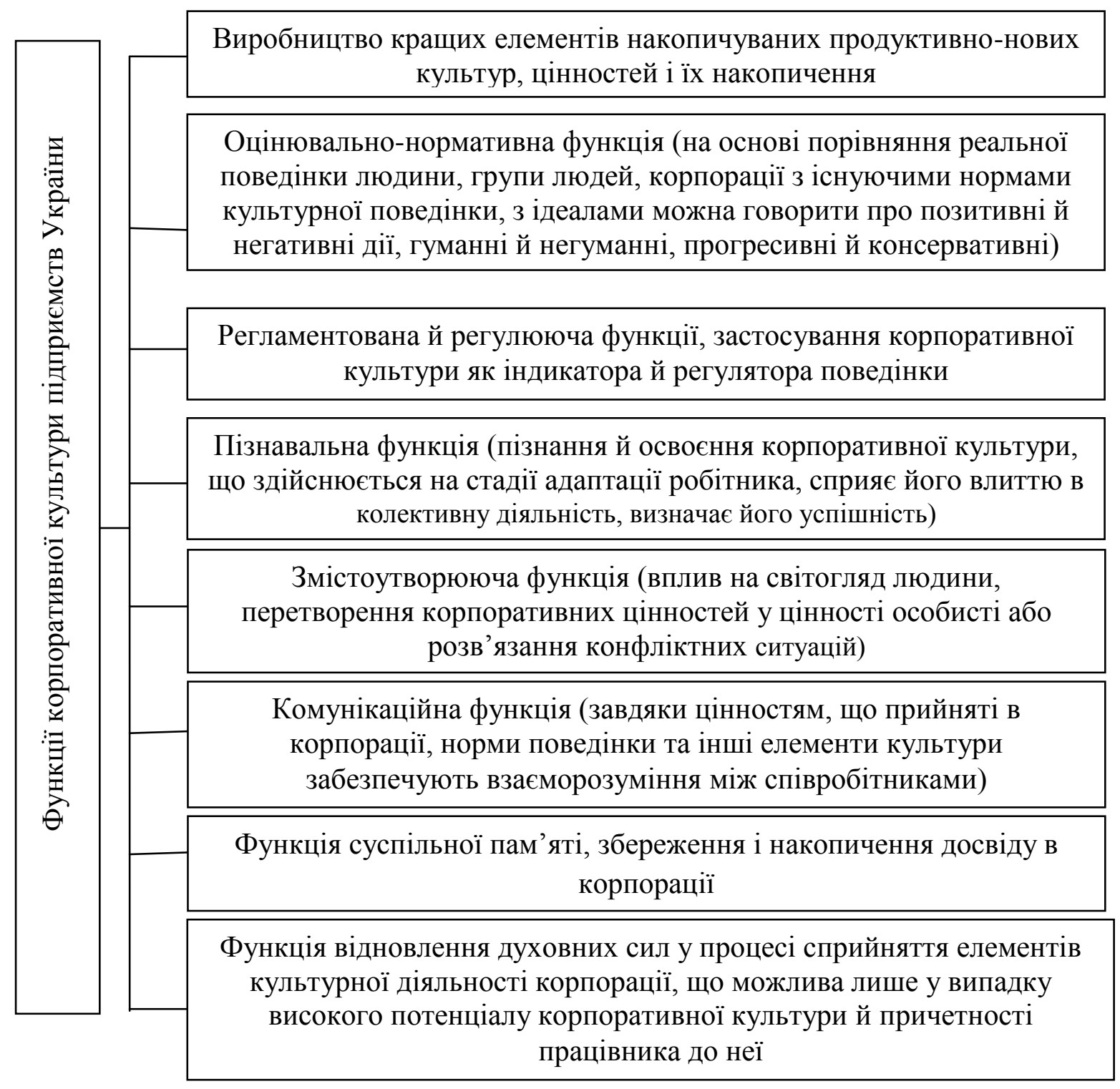

Рисунок 2 - Функції корпоративної культури підприємства [4]

На всіх етапах розвитку України суттєвий вплив на іiі економічне середовище й економічну культуру мали ті чи інші особливості проживання людей у сільській чи міській місцевості, зокрема, національного буття, національного характеру, суспільної свідомості та психології українців.

Попри підвищену потребу українського бізнесу до побудови системи корпоративної культури в межах власних підприємств, у спеціальній літературі практично відсутні напрацювання щодо теоретичних, методологічних та організаційних засад побудови корпоративної культури 3 врахуванням специфічних ознак підприємства.

Стосовно питань, які є предметом цього дослідження, констатуємо, що технологія організації корпоративної культури 3 урахуванням специфіки діяльності підприємства повинна базуватися на встановленій організаційній 
структурі, в рамках якої можуть провадитися необхідні види діяльності 3 визначенням відповідального за кожний окремий вид діяльності, а також 3 визначенням відповідальності управлінського персоналу.

Особливо важливе значення в зазначеному контексті мають національний характер і ментальність. Національний характер $\epsilon$ важливою складовою будь-якої національної культури, у тому числі й корпоративної. Національний характер являє собою не стільки сукупність психологічних явищ, скільки буття, форми самоусвідомлення народу [4].

3 одного боку, розвиток національного характеру залежить від стану розвитку суспільства, держави, права, економічної культури, від можливості людини реалізувати свої права й свободи. 3 іншого боку, національний характер здійснює суттєвий вплив на соціально-економічний розвиток суспільства. У національному характері українців, їх ментальності існує ціла низка рис, які не підходять до загальновизнаних норм корпоративної культури. Витоки невисокого рівня економічної культури, зокрема, економічний нігілізм, позапублічність життя, етнічна психологія нашого народу, що формувались упродовж багатьох століть.

Система корпоративної культури повинна бути адаптованою до організаційної структури підприємства.

Висновки. Таким чином можна стверджувати, що корпоративна культура організації - це сукупність прийнятих на даному підприємстві норм і правил поведінки по відношенню до клієнтів і партнерів, а також культура міжособистих стосунків на підприємстві і саме від неї залежить ефективність діяльності організації, стан міжособистісних стосунків в ній та сформований імідж.

Тому при побудові (або реорганізації) системи корпоративної культури для конкретного підприємства доцільно розглядати його галузеву специфіку не в межах окремих видів економічної діяльності, а 3 огляду на наявність п'яти специфічних ознак, які характеризують галузеву специфіку та визначають специфіку формування корпоративної культури на підприємстві.

Основний науковий результат полягає в розробленні параметрів впливу на формування корпоративної культури підприємства 3 урахуванням специфіки галузі, яка б повністю відповідала вимогам сучасності.

Врахування викладених теоретичних та організаційних засад специфіки підприємств при формуванні корпоративної культури забезпечить його подальшу дієвість та загальну ефективність управління підприємством.

\section{Література:}

1. Кузьмін О.С., Бала О.І., Бала Р.Д. Фактори впливу на корпоративну культуру: сутність та класифікація. Економіка: проблеми теорії та практики: Збірник наукових пращь. Випуск 222: в 5.т., т. V. Дніпропетровськ: ДНУ, 2007.С.1078-1083. 
2. Давиденко Н.М. Особливості формування корпоративної культури на підприємствах АПК України. Актуальні проблеми розвитку економіки регіону. 2011. Вип. 7(1). C. 161-165URL:http://www.pu.if.ua/depart/Finances/resource/file

3. Зеркаль А.В. Особливості формування корпоративної культури у галузі машинобудування. Ефективна економіка. 2012.

3.URL:http://www.economy.nayka.com.ua/?op=1\&z=1029

4. Кузнецова С.А., Кузнецов А.А. Формування корпоративної культури в залежності від специфіки підприємства. Проблеми економіки. 2011. № 4. URL:http://www.problecon.com/export_pdf/problems-of-economy-2011-4_0-pages-91_94.pdf

5. Фіщук Н.Ю., Ломачинська І.В. Корпоративна культура організації: сутність, види, принципи та вплив на розвиток організації. Збірник наукових праць ВНАУ. Серія: Економічні науки. URL:http://econjournal.vsau.org/files/pdfa/691.pdf 